\title{
Examine the Underlying Causes of Flexible Pavement Deteriorations, Methods of Maintenance and Pavement Condition Rating
}

\author{
Pooja Kherudkar, Namdeo A. Hedaoo
}

\begin{abstract}
In India, the deterioration of asphalt pavement is a major issue in the road and highway sectors. It may occur due to a variety of factors such as premature aging, improper mix design, inadequate construction, and material quality, the improper structure design of pavement considering traffic, and a lack of preventive maintenance, among others. There are many types of distress in asphalt pavements known as disintegration (raveling, and potholes), fracture (spalling and cracking), and distortion (slippage deformation of permanent). This research aims to perform a physical survey for distress analysis and pavement condition rating using the IRC method. As a case study, four urban flexible pavement roads in the Pimpri Chinchwad Pune area were chosen. The roads are visually inspected to measure the severity to detect the types and extent of the distresses. Based on the severity of the distresses, the IRC method assigns a grade of 0 to 1.0 for poor condition roads, 1.1 to 2.0 for fair condition roads, and 2.1 to 3.0 for good condition roads. As per the pavement condition rating, two of the four urban roads were found to be in fair condition, while the other two were in poor condition. The cost-effective treatments were recommended from a variety of treatments such as slurry seal, fog seal, crack seal, micro-surfacing, thin cold or hot mix bituminous overlays, and surface dressing.
\end{abstract}

Keywords: Surface distress measurement, Physical survey, Distress analysis, Pavement condition rating, the cost-effectiveness of treatment.

\section{INTRODUCTION}

There are several causes of distresses of Flexible Pavement. The causes of road deterioration are various and vary from one road to the next. Several rehabilitation and maintenance treatments are performed to minimize the deterioration of pavements and enhance the life of the flexible pavements [1]. Various Common Causes of failures of flexible pavements is due to Inadequate asphalt mix design, Poor quality of materials and/or construction, Inadequate

Manuscript received on April 21, 2021.

Revised Manuscript received on April 26, 2021.

Manuscript published on April 30, 2021.

* Correspondence Author

Ms. Pooja Kherudkar*, M. Tech Student, Department of Civil Engineering, Government College of Engineering, Pune, India.

Email: nah.research2020@gmail.com

Dr. Namdeo A. Hedaoo, Associate Professor, Department of Civil Engineering, Government College of Engineering, Pune, India. Email: hedaoonamdeo@gmail.com

(C) The Authors. Published by Blue Eyes Intelligence Engineering and Sciences Publication (BEIESP). This is an open access article under the CC BY-NC-ND license (http://creativecommons.org/licenses/by-nc-nd/4.0/) pavement structural thickness, Amount of traffic more than that anticipated in pavement design, and rate of loading different than that anticipated in pavement design, Aging of asphalt binders which does happen at slow rates except in cases where high air voids in an asphalt pavement may accelerate aging, Effect of climate in terms of high and low temperatures and rainfall, and Lack of preventive maintenance [6]. Distress analysis for flexible pavement is the systematic examination, evaluation of the surface condition of the pavement for detecting the distresses, their types, severity, and extent. Distress analysis is carried out to determine the pavement condition rating for roads to rate the current condition of its surfaces, provide maintenance and rehabilitation treatments [3], [8]. The distresses are investigated by visual inspection and the possible causes of deterioration are enlisted. The analysis is done based on the pavement distress manuals and the PCR values are calculated. The cost-effective rankings of the maintenance treatment are recommended [5].

Reasons for the occurrence of distresses in India:

1. A major cause of cracking is an increase in traffic load, particularly on new roads where the design is focused on less traffic. When a good road is built, traffic from other roads switches to that road and this leads the fatigue failure (Alligator Cracking).

2. The reason behind edge failures is the provision of poor shoulders.

3. Corrugation at the surface and increased unevenness result from the use of a poor clayey subgrade.

4. Particularly during rainy seasons, poor drainage causes water to reach the pavement from the sides and top surface; as the top layer separates from the lower layers, this process becomes more dangerous,

5. Pavement failure will also occur if the temperature of the bitumen/bituminous mixes is not adequately controlled. Bitumen's binding property is reduced when it is overheated. If the temperature of the bituminous mix is reduced, the compaction would be inadequate, resulting in longitudinal corrugation [9].

Effects of the failures:
1. Accidents.
2. Increase in faulty vehicles.
3 . Waste of journey time.
4. Traffic congestion.
5. Cause of soil erosion.

Published By:

Blue Eyes Intelligence Engineering and Sciences Publication

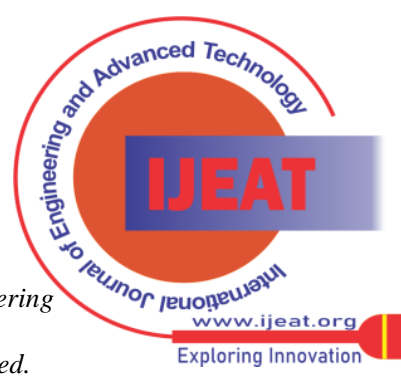




\section{Adverse economic development}

\section{OBJECTIVE OF STUDY}

- To identify and analyze the type of distresses based on the guidelines of IRC: 82-2015.

- To identify causes of deterioration of flexible pavements.

- To provide the proper maintenance and rehabilitation treatments

- To carry out the cost-effectiveness of the treatments

\section{METHODOLOGY}

\section{A. DATA ANALYSIS}

In this part of the collection of data, periodic site visits were carried out for identification of the forms of distresses, their measurement and severity, and extent determination of the distresses.

The data is collected from four, urban roads in Pune city. The data is collected manually by conducting actual measurements of the deteriorations using measurement tape and other measurement devices. The length, width, depth and other parameters of the distresses were recorded and tabulated. The photos related to the observations were taken and recorded. The lengths and widths of the four roads were as follows:

A. Shinde Vasti Chowk to Iskon Temple road, Ravet Pimpri Chinchwad Pune. (Length: - 1000m and Width: $-7 \mathrm{~m})$

B. Road besides Dmart Survey No 29, Ravet Pimpri Chinchwad Pune.

(Length: - 310m and Width: - 8m)

C. Ravet Gaothan School to Livle Gaothan road Pimpri Chinchwad Pune.

(Length: - 1500m and Width: - 7m)

D. Road Infront of Dmart, Survey No 29, Ravet Pimpri Chinchwad Pune.

(Length: - 240m and Width: - 7m)

The severity and extent of the four individual roads (urban flexible roads) of Pune city are determined based on the guidelines of IRC: 82-2015 distresses identification manual [4]. The lane wise PCR values have been determined by IRC method. Various maintenance treatments have been recommended and the most cost-effective treatment is identified [2]. The actual database is created for four roads. In this database as per guidelines from the code of practice for maintenance of Bituminous roads (IRC: 82-2015), the severity and extent are calculated. The most common types of distresses observed based on an actual database which is Alligator Cracking, Edge Cracking, Longitudinal Cracking, Transverse Cracking, Edge Breaking, Bleeding, Potholes, Raveling, Rutting, and Shoving.

\section{B. PAVEMENT DISTRESSES}

Alligator Cracking: This is characterized as a series of interconnected cracks, which resembles the skin of an alligator. These types of cracks occur due to the overloading of heavy commercial vehicles, brittleness of the binder due to aging of the binder.

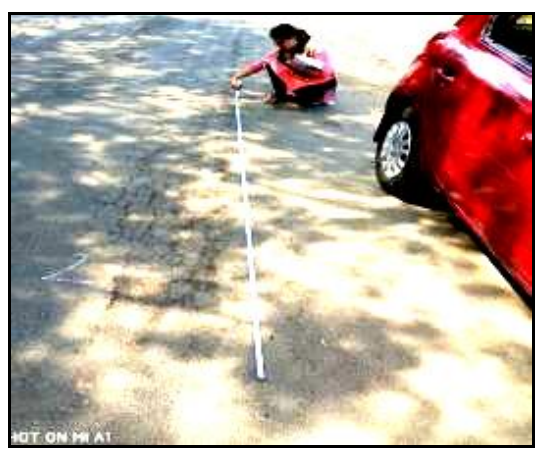

Fig. 1 Low Severity

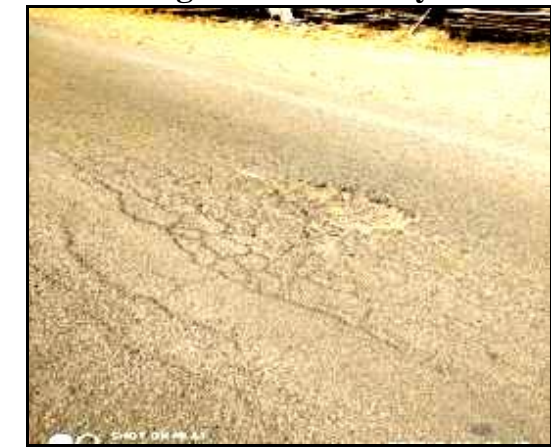

Fig. 2 Medium Severity

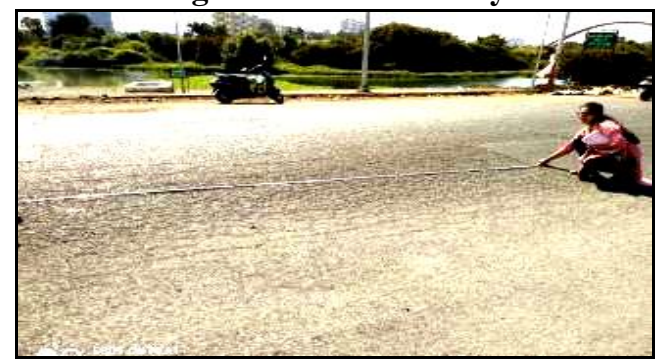

Fig. 3 High Severity

Longitudinal Cracking: Cracks that appear parallel to the centerline or along the road are called longitudinal cracks. These are usually caused by alternate wetting and drying beneath the shoulder surface or by improper/weak joints between adjoining layers of pavement.

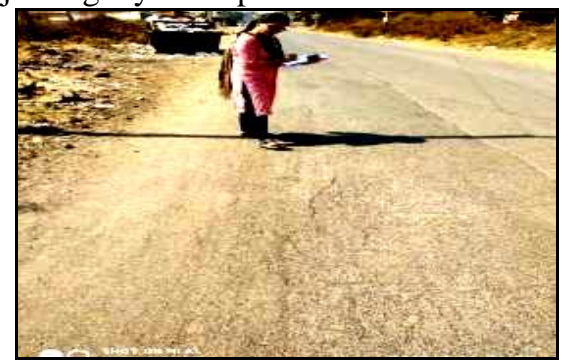

Fig. 4 Low Severity

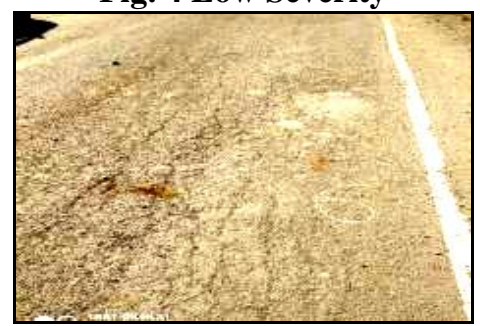

Fig. 5 Medium Severity

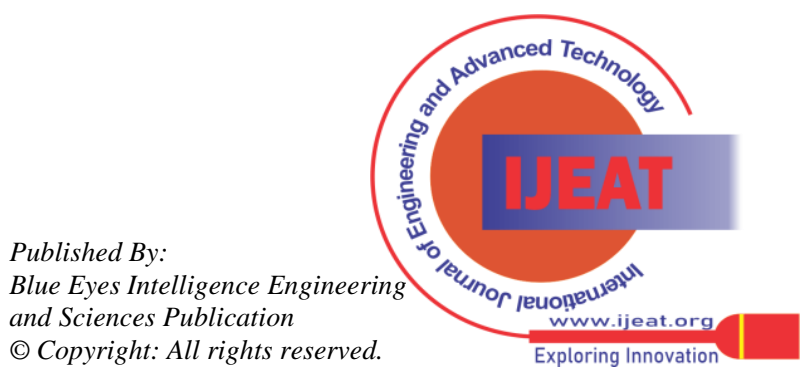




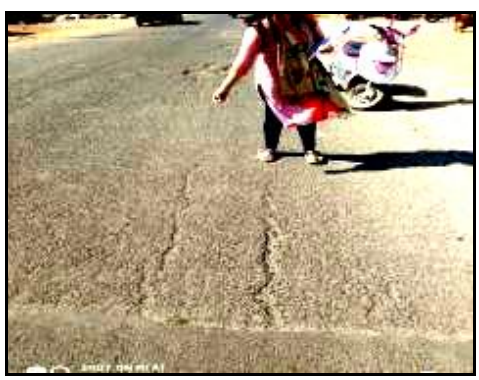

Fig. 6 High Severity

Transverse Cracks: These cracks appear in the transverse direction or as interconnected cracks forming series of large blocks perpendicular to the direction of the road. These may occur due to the reflection of crack or joint in an underlying pavement layer, due to shrinkage of bituminous mix on account of low temperature.

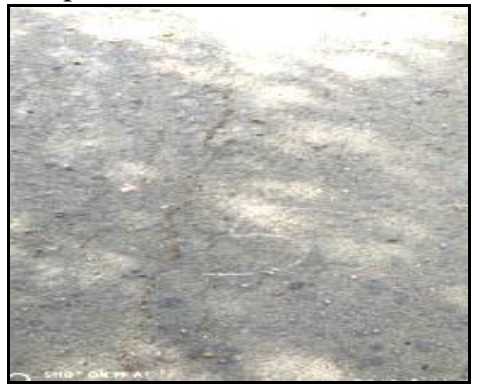

Fig. 7 Low Severity

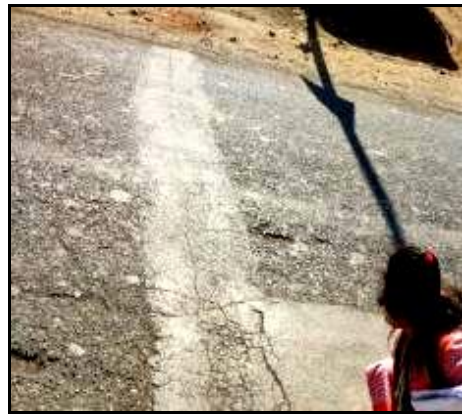

Fig. 8 Medium Severity

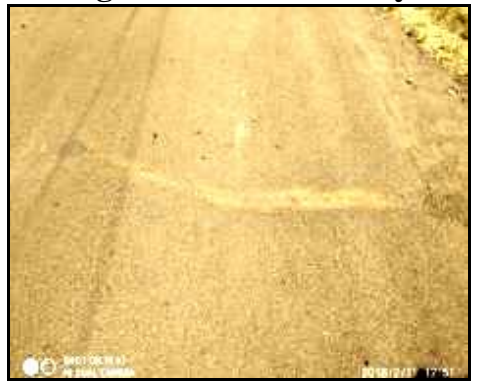

Fig. 9 High Severity

Edge Cracking: The cracks which develop parallel to the outer edge of the pavement.

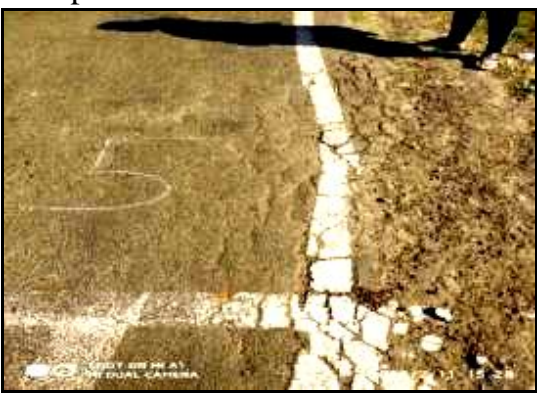

Fig. 10 Low Severity

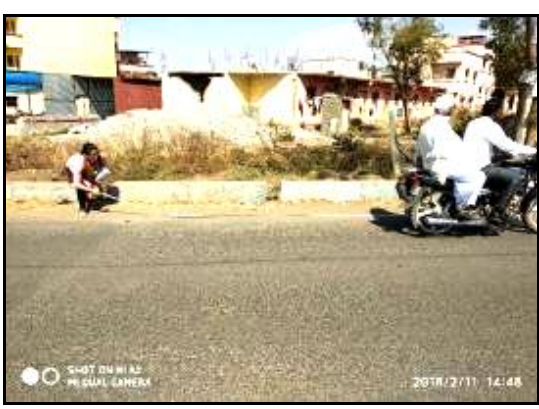

Fig. 11 Medium Severity

Rutting: Rutting is longitudinal depression or groove in the pavement along the wheel path. These occur due to heavy channelized traffic and overloading of vehicles and from unstable asphalt courses due to poor asphalt mix design. (especially use of rounded aggregate, improper gradation, and excessive bitumen binder). It can also occur If there is a lack of adequate subgrade support which causes the whole pavement to settle in the wheel tracks where loads are applied.

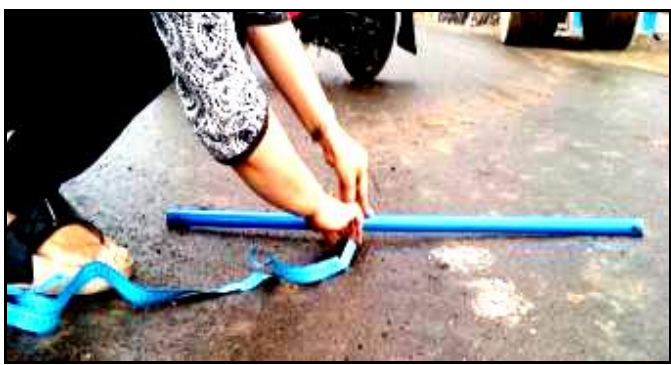

Fig. 12 Low Severity

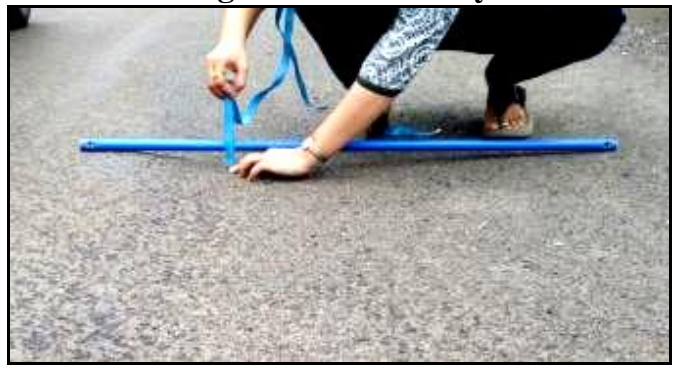

Fig. 13 High Severity

Shoving: This is a form of plastic movement within the bituminous layers resulting in bulging of the pavement surface. This occurs due to less mix stability (high proportion of fines, excessive binder, soft binder) in the bituminous surface or base course, and lack of bonding between underlying layer and bituminous surface.

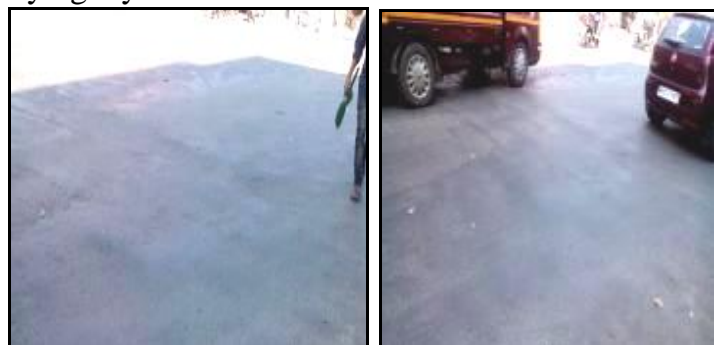

Fig. 14 Bulging of Bituminous Layer

Published By:

Blue Eyes Intelligence Engineering and Sciences Publication

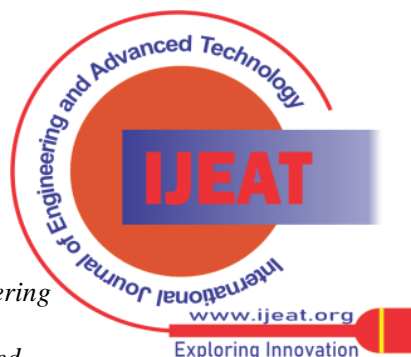


Raveling: The dissociation and progressive separation of fine aggregate particles and binder from the bituminous surface is known as raveling. Normally fine aggregates wear away first followed by coarse aggregates. It occurs due to a lack of sufficient cohesion within asphalt mix due to low in-place density or inadequate binder content. Lack of fines in the asphalt mix matrix, especially in the course, segregated areas also cause premature raveling. Aging of asphalt binder can also cause raveling but it takes place after many years of service.

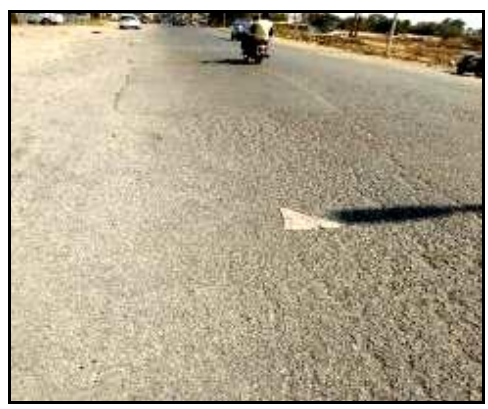

Fig. 15 Low Severity

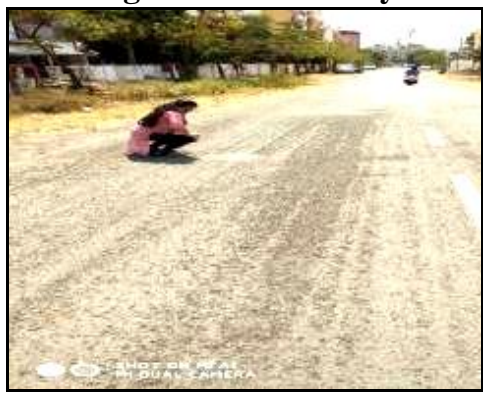

Fig. 16 Medium Severity

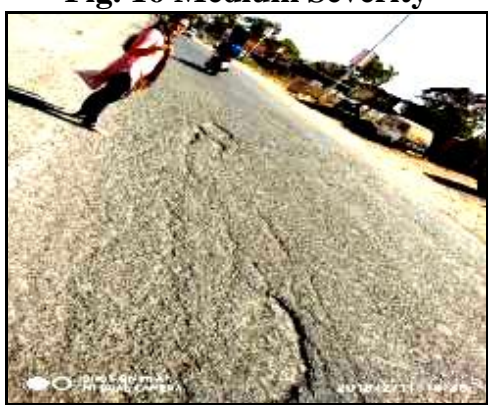

Fig. 17 High Severity

Potholes: The various sizes of bowl-shaped cavities in a bituminous surface or extending into the binder/base course are known as potholes. Severe cases of fatigue cracking culminate in the formation of potholes on the asphalt road. Potholes also develop when there is a lack of support from the unbound courses due to excessive moisture.

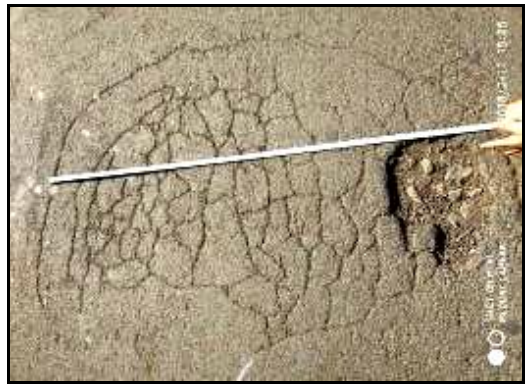

Fig. 18 Low Severity
Edge Breaking: The common defect in the bituminous surface is edge breaking wherein the edge of the bituminous surface gets broken irregularly.

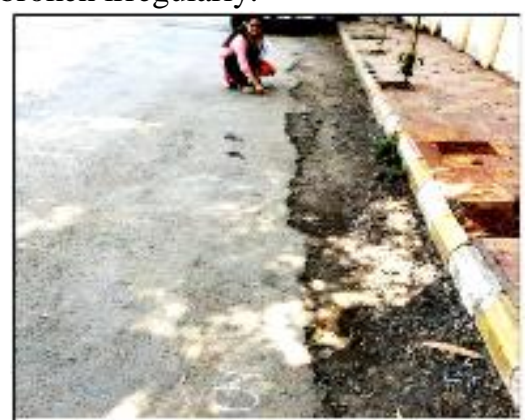

Fig. 21 Edge Breaking

Bleeding: A surface having a thin film of excess or free bituminous binder on it, which creates a shiny glass like reflecting surface tending to become soft in hot weather and slippery in cold and wet weather eventually developing low skid resistance. Bleeding may occur due to excessive binder in the mix design or due to poor quality control, low air voids in the compacted mat, use of low viscosity bitumen binder, too heavy tack coat, excessive binder application and/or loss of cover aggregate in case of surface dressing.

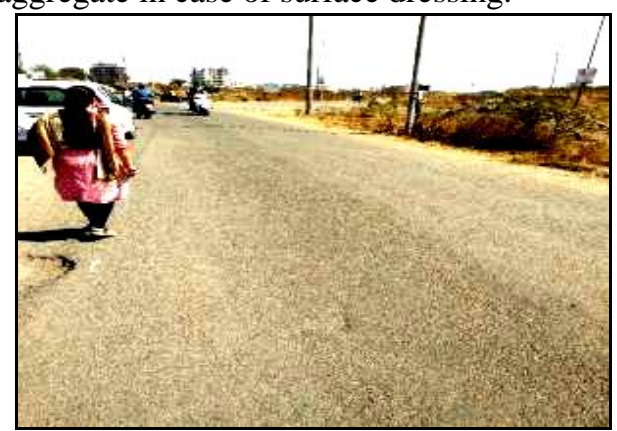

Fig. 22 Bleeding of Bituminous Layer

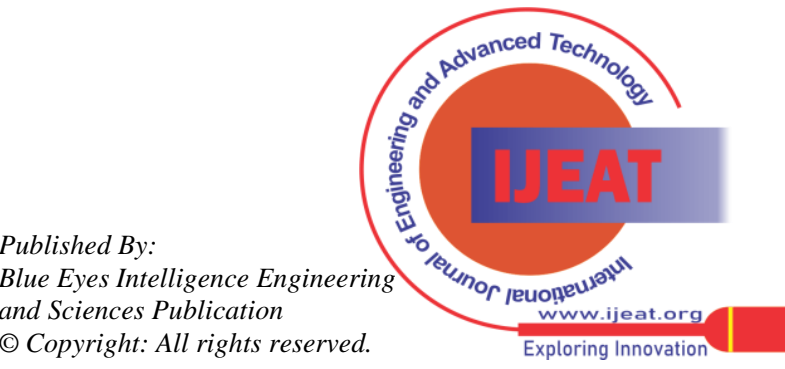




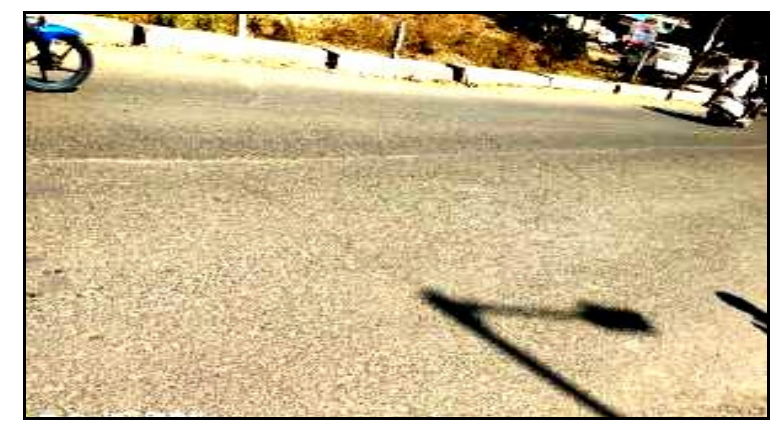

Fig. 23 Bleeding of Bituminous Layer

Slippage: Slippage is caused by the unusual thrust of wheels in a specific direction due to inadequacy of tack coat, lack of bond between the wearing coat and the lower layer caused by a layer of fine dust, moisture, or both. Failure of a bond between two layers due to excessive deflection of the pavement may also be responsible for slippage of wearing a coat or successive layers.

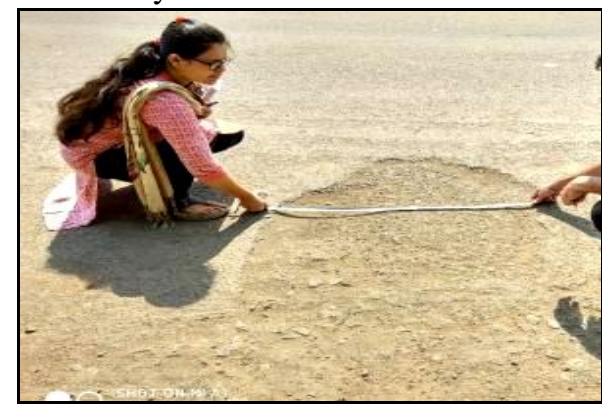

Fig. 24 Low Severity

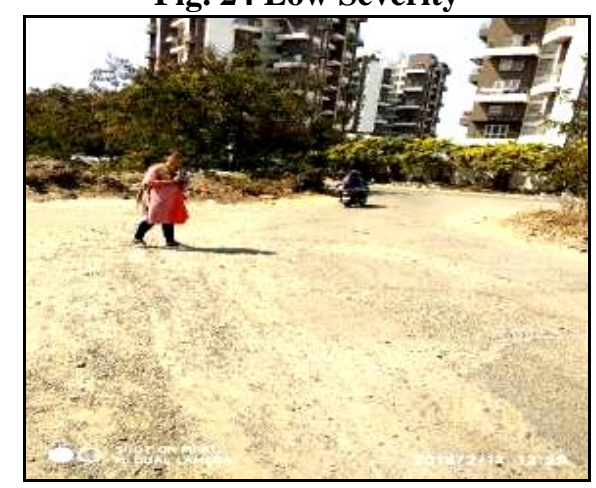

Fig. 25 High Severity

Settlements: During a highway expansion scheme, the full differential settlement occurs at the overlapping location between old and new road pavement. When the old road's base is stronger, the maximum settling on the land surface falls toward the current embankment.

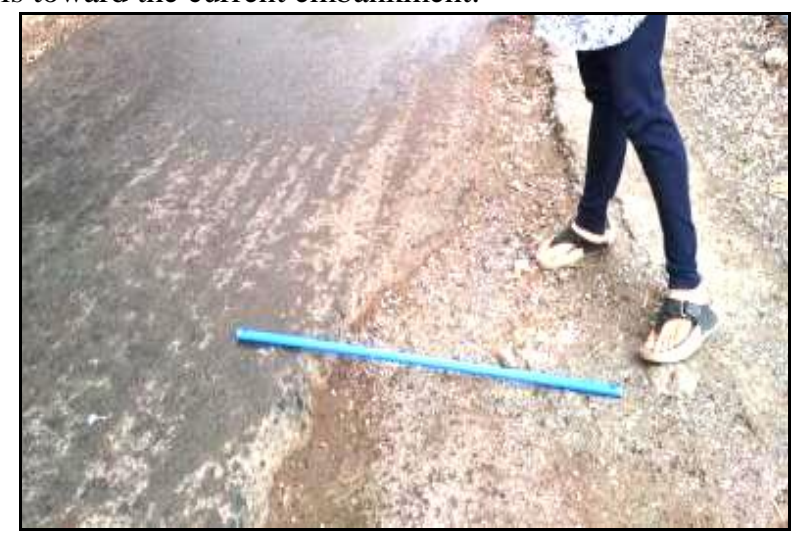

Fig. 26 Settlements

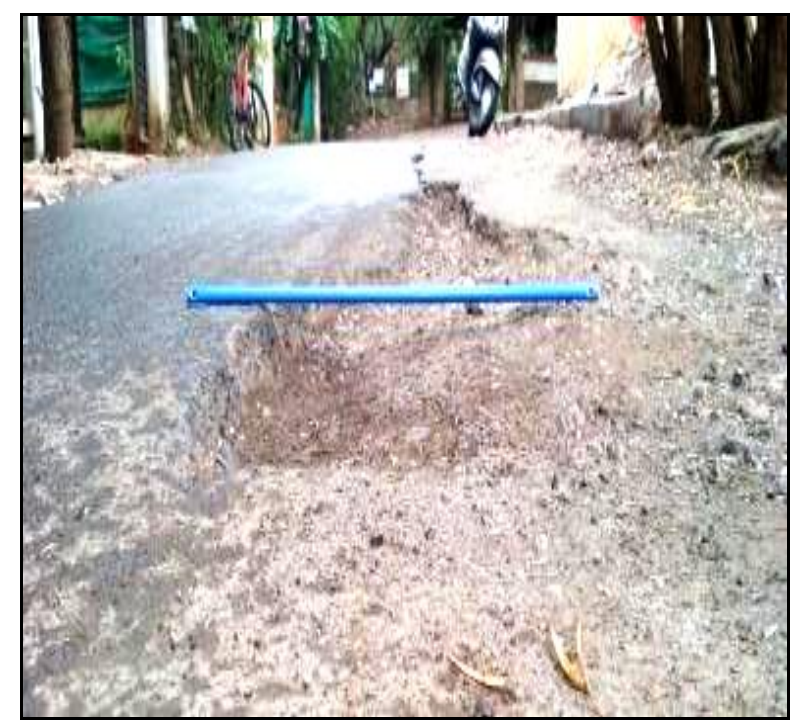

Fig. 27 Settlements

\section{PAVEMENT CONDITION RATING}

The pavement condition rating is analyzing and evaluating for each segment in the length of the road. PCR can be determined by manual visualization and that has to be conducted periodically and the numerical rating for the poor condition of roads is 1 , for the fair condition of roads is 1.1 to 2 , and for the good condition of roads, it is 2.1 to 3 [5].

\section{OBSERVATIONS}

The Surface distress measurement and the PCR calculation based on IRC has been carried out as follows:

1. Surface Distress Measurement for Field Survey - A:

Name of the road: - Shinde vasti chowk to Iskon temple road Ravet, Pimpri Chinchwad, Pune.

Carriageway width: $-7 \mathrm{~m}$

Type of Pavement: - Asphalt pavement

Chainage test sections: - 0 to $0.5 \mathrm{Km}$.

Shinde Vasti Chowk to Iskon Temple road is situated in the Ravet area Pimpri Chinchwad Pune. This road is under PCMC scheme. This road was constructed in the year 2011. The total road length constructed is $1000 \mathrm{~m}$ with a structural layer of Granular Sub-base course of 150mm thick, Wet Mix Macadam layer of $150 \mathrm{~mm}$ thick, Bituminous bound macadam layer of $75 \mathrm{~mm}$ thick, $20 \mathrm{~mm}$ premix bituminous carpet, Liquid seal coat. Due to leakage in old drainage, excavation was carried out for new drainage and hence potholes occurred which were then sealed by patching with cold mix.

I. For Chainage test sections: - 0 to $0.5 \mathrm{Km}$.

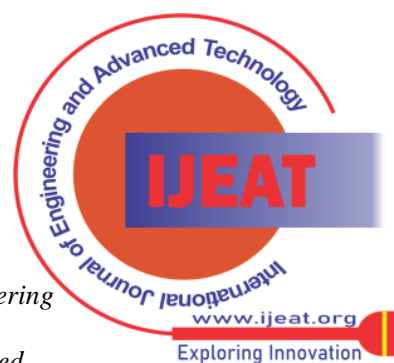


Examine the Underlying Causes of Flexible Pavement Deteriorations, Methods of Maintenance and Pavement Condition Rating

Table 1: Surface Distress Measurement of Asphalt

Pavement, chainage section 0 to $0.5 \mathrm{~km}$ as per IRC: 82-2015

\begin{tabular}{|c|c|c|c|c|c|c|c|}
\hline $\begin{array}{l}\text { Sr. } \\
\text { No }\end{array}$ & Type & Severity & $\begin{array}{l}\text { Length } \\
\text { (m) }\end{array}$ & $\begin{array}{c}\text { Breadth } \\
\text { (m) }\end{array}$ & $\begin{array}{l}\text { Dept } \\
\text { h (m) }\end{array}$ & $\begin{array}{l}\text { Area } \\
\left(\mathbf{m}^{2}\right)\end{array}$ & $\begin{array}{l}\text { Total } \\
\text { Area } \\
\left(\mathbf{m}^{2}\right)\end{array}$ \\
\hline \multirow{11}{*}{1.} & \multirow{11}{*}{$\begin{array}{l}\text { Alligator } \\
\text { Cracking }\end{array}$} & Medium & 2.50 & 1.50 & - & 3.75 & \\
\hline & & Low & 2.00 & 1.50 & - & 3.00 & \\
\hline & & Medium & 2.50 & 1.25 & - & 3.13 & \\
\hline & & Medium & 1.50 & 0.80 & - & 1.20 & \\
\hline & & Low & 1.50 & 1.00 & - & 1.50 & \\
\hline & & Low & 1.75 & 1.50 & - & 2.62 & \\
\hline & & Medium & 2.00 & 1.75 & - & 3.50 & \\
\hline & & Low & 3.00 & 1.50 & - & 4.50 & \\
\hline & & Medium & 2.00 & 2.75 & - & 5.50 & \\
\hline & & Medium & 2.50 & 1.75 & - & 4.38 & \\
\hline & & \multicolumn{4}{|c|}{ Total (0 to $0.5 \mathrm{~km})$} & 33.08 & \\
\hline \multirow{4}{*}{2.} & \multirow{4}{*}{$\begin{array}{c}\text { Edge } \\
\text { Cracking }\end{array}$} & Low & 3.75 & 0.45 & - & 1.70 & \\
\hline & & Medium & 2.50 & 1.00 & - & 2.50 & \\
\hline & & Low & 3.55 & 1.00 & - & 3.55 & \\
\hline & & \multicolumn{4}{|c|}{ Total $(0$ to $0.5 \mathrm{~km})$} & 7.75 & \\
\hline \multirow{7}{*}{3.} & \multirow{7}{*}{$\begin{array}{c}\text { Longitudi } \\
\text { nal } \\
\text { Cracking }\end{array}$} & Low & 1.00 & 0.25 & - & 0.25 & \\
\hline & & High & 1.25 & 1.40 & - & 1.75 & \\
\hline & & Medium & 2.00 & 1.45 & - & 2.90 & \\
\hline & & Medium & 2.50 & 3.00 & - & 7.50 & \\
\hline & & Low & 2.75 & 2.00 & - & 5.50 & \\
\hline & & Medium & 1.40 & 2.60 & - & 3.64 & \\
\hline & & \multicolumn{4}{|c|}{ Total (0 to $0.5 \mathrm{~km})$} & 21.54 & \\
\hline \multirow{3}{*}{4.} & \multirow{3}{*}{$\begin{array}{c}\text { Transverse } \\
\text { Cracking }\end{array}$} & Medium & 7.00 & 0.50 & - & 3.50 & \\
\hline & & Low & 3.80 & 0.75 & - & 2.85 & \\
\hline & & \multicolumn{4}{|c|}{ Total (0 to $0.5 \mathrm{~km})$} & 6.35 & \\
\hline \multicolumn{7}{|c|}{ Total Cracking (0 to $0.5 \mathrm{~km}$ ) } & 68.72 \\
\hline \multirow{2}{*}{5.} & \multirow{2}{*}{$\begin{array}{c}\text { Edge } \\
\text { Breaking }\end{array}$} & - & 3.93 & 0.25 & - & 0.98 & \\
\hline & & - & 6.00 & 0.30 & - & 1.80 & \\
\hline \multicolumn{7}{|c|}{ Total Edge Breaking (0 to $0.5 \mathrm{~km}$ ) } & 2.78 \\
\hline \multirow{2}{*}{6.} & \multirow{2}{*}{ Bleeding } & - & 3.50 & 0.17 & - & 0.62 & \\
\hline & & - & 1.40 & 1.50 & - & 2.10 & \\
\hline \multicolumn{7}{|c|}{ Total Bleeding (0 to $0.5 \mathrm{~km}$ ) } & 2.72 \\
\hline \multirow{8}{*}{7.} & \multirow{8}{*}{ Potholes } & Large & 0.70 & 0.65 & 0.063 & 0.52 & \\
\hline & & Medium & 0.69 & 0.38 & 0.039 & 0.27 & \\
\hline & & Medium & 0.45 & 0.65 & 0.05 & 0.3 & \\
\hline & & Small & 0.41 & 0.29 & 0.025 & 0.12 & \\
\hline & & Medium & 0.80 & 0.45 & 0.028 & 0.36 & \\
\hline & & Medium & 0.60 & 0.72 & 0.030 & 0.432 & \\
\hline & & Medium & 0.57 & 0.59 & 0.043 & 0.34 & \\
\hline & & Small & 0.33 & 0.27 & 0.023 & 0.09 & \\
\hline \multicolumn{7}{|c|}{ Total Potholes ( 0 to 0.5 km) } & 2.44 \\
\hline & & Low & 32.57 & 2.00 & - & 65.14 & \\
\hline 8 & & Medium & 18.30 & 2.35 & - & 43.00 & \\
\hline 8. & Raveling & Low & 20.42 & 1.75 & - & 35.73 & \\
\hline & & Medium & 12.70 & 3.00 & - & 38.10 & \\
\hline & & Total & veling $(0 t$ & $.5 \mathrm{~km})$ & & & 182 \\
\hline
\end{tabular}

II. For Chainage test sections: -0.5 to $1 \mathrm{Km}$.

Table 2: Surface Distress Measurement of Asphalt

Pavement, chainage section 0.5 to $1 \mathrm{~km}$ as per IRC: 82-2015

\begin{tabular}{|c|c|c|}
\hline Type of Distress & Total & \% Distress \\
\hline Cracking & $142.58 \mathrm{~m}^{2}$ & $(142.58 / 7000) \times 100=2.04 \%$ \\
\hline Edge Breaking & $4.47 \mathrm{~m}^{2}$ & $(4.47 / 7000) \times 100=0.064 \%$ \\
\hline Bleeding & $3.76 \mathrm{~m}^{2}$ & $(3.76 / 7000) \times 100=0.05 \%$ \\
\hline Potholes & $5.39 \mathrm{~m}^{2}$ & $(5.39 / 7000) \times 100=0.08 \%$ \\
\hline Raveling & $351.90 \mathrm{~m}^{2}$ & $(352 / 7000) \times 100=5.03 \%$ \\
\hline Rutting & $0.012 \mathrm{~mm}$ & - \\
\hline
\end{tabular}

Summary of Surface Distress Measurement of Asphalt Pavement: Calculation of Final Rating Values based on quantity (\%) of distress:

Table 3: Summary of Surface Distress Measurement of Asphalt Pavement, chainage section 0 to $1 \mathrm{~km}$ as per IRC: 82-2015

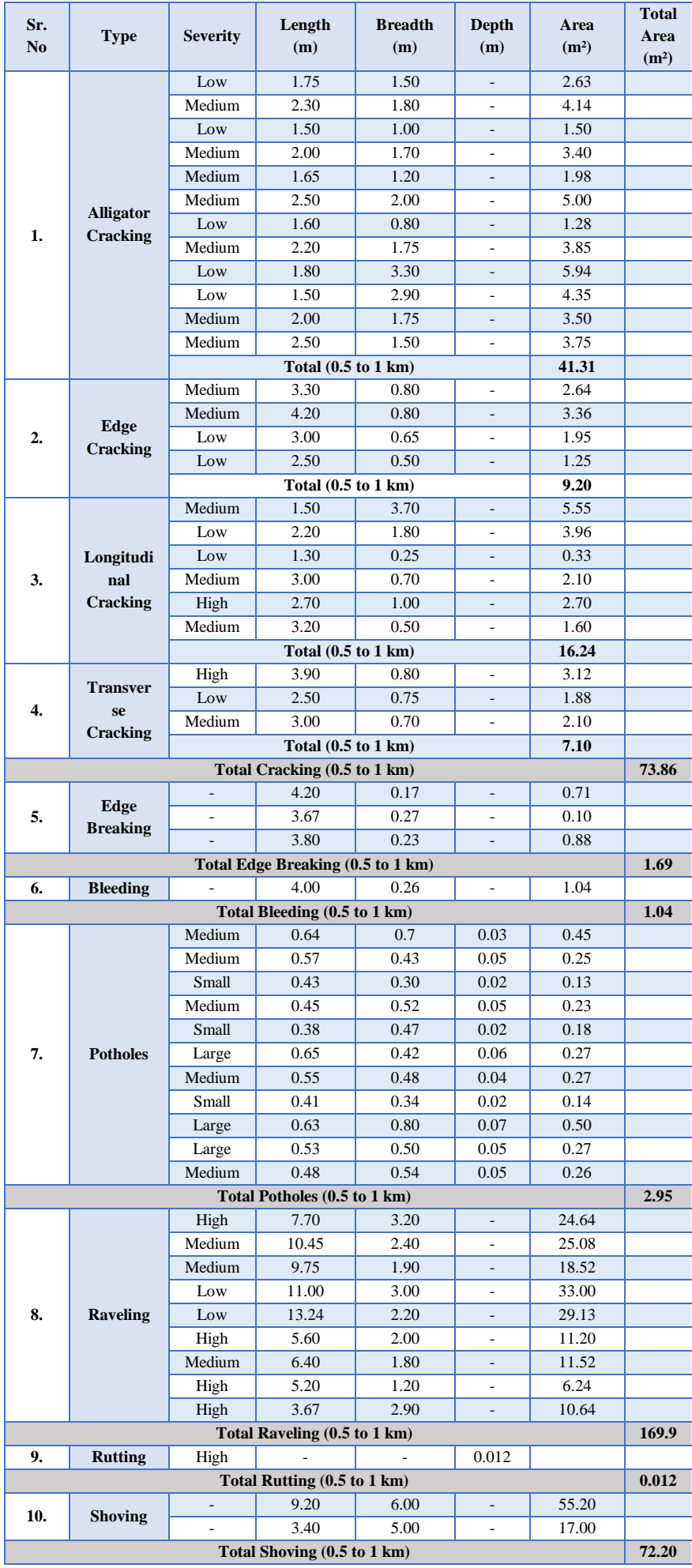

Table 4: Calculation of Final Rating Values as per IRC: 82-2015

\begin{tabular}{|c|c|c|c|c|}
\hline $\begin{array}{c}\text { Type of } \\
\text { Distress }\end{array}$ & Input & $\begin{array}{c}\text { Distress } \\
\text { Rating }\end{array}$ & $\begin{array}{c}\text { Weightage } \\
\text { (Multiplier } \\
\text { Factor) }\end{array}$ & $\begin{array}{c}\text { Weighted } \\
\text { Rating } \\
\text { Value }\end{array}$ \\
\hline Cracking & $2.04 \%$ & 2.70 & 1.00 & 2.70 \\
\hline Potholes & $0.08 \%$ & 1.80 & 0.50 & 0.90 \\
\hline Raveling & $5.03 \%$ & 2.00 & 0.75 & 1.50 \\
\hline Settlements & $0.01 \%$ & 3.00 & 0.75 & 2.25 \\
\hline Rutting & $12 \mathrm{~mm}$ & 1.00 & 1.00 & 1.00 \\
\hline \multicolumn{5}{|c|}{ Final Rating Value } \\
\hline \multicolumn{5}{|c|}{ Condition } \\
\hline
\end{tabular}

Published By:
Blue Eyes Intelligence Engineering and Sciences Publication

(C) Copyright: All rights reserved.

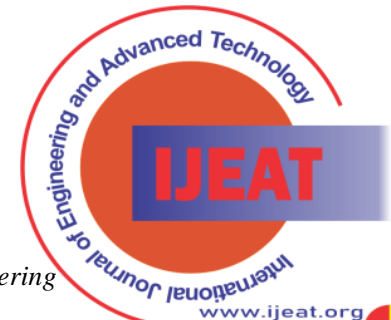
Exploring Innovation 


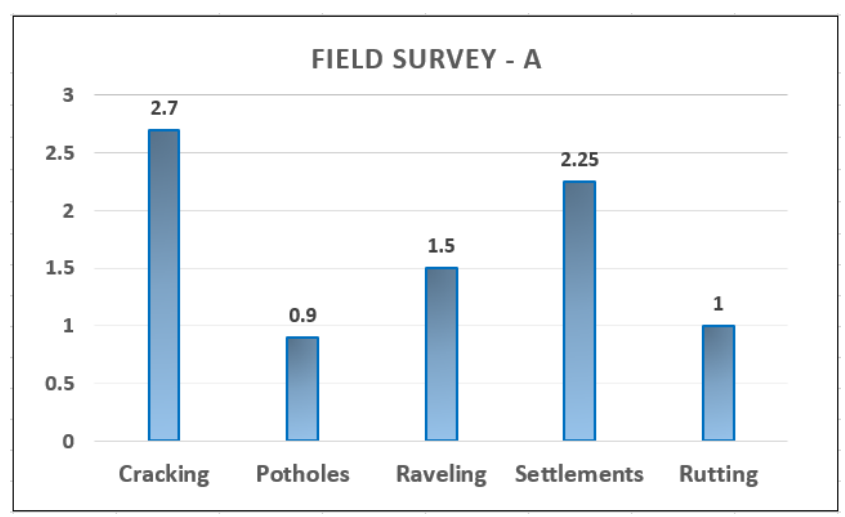

Graph 1: Observed distress rating value for Field Survey - A For field survey - A, the final rating value is obtained 1.67 which is in between 1.1 to 2.0 and according to that, the road is in fair condition.

Similarly, all reading of Surface Distress Measurement of Asphalt Pavement is calculated for Field Survey - B, Field Survey - C, and for Field Survey - D as well and shown in the summary of distress measurement table as shown in follows:

\section{Surface Distress Measurement for Field Survey - B:}

Name of the road: - Road besides Dmart, Survey No 29, Ravet, Pimpri Chinchwad, Pune.

Carriageway width: - $8 \mathrm{~m}$

Type of Pavement: - Asphalt Pavement

Chainage test section: - 0 to $0.310 \mathrm{~km}$

Road beside Dmart, Survey No. 29 situated in Ravet area Pimpri Chinchwad Pune. This road is under PCMC scheme This road was constructed in the year 2013. The total road length constructed is $310 \mathrm{~m}$ with a structural layer of Granular Sub-base course of $150 \mathrm{~mm}$ thick, Wet Mix Macadam layer of $150 \mathrm{~mm}$ thick, Bituminous bound macadam layer of $75 \mathrm{~mm}$ thick, 20mm premix bituminous carpet, Liquid seal coat. This road was excavated for a new water supply pipeline, therefore due to improper filling and due to the traffic load on the patch that was excavated potholes were seen, and hence patching work was done using the cold mix.

Summary of Surface Distress Measurement of Asphalt Pavement:

Table 5: Summary of Surface Distress Measurement of Asphalt Pavement, chainage section 0 to $0.310 \mathrm{~km}$ as per IRC: 82-2015

\begin{tabular}{|c|c|c|}
\hline Type of Distress & Total & \% Distress \\
\hline Cracking & $99.2 \mathrm{~m} 2$ & $(99.2 / 2480) \times 100=4 \%$ \\
\hline Edge Breaking & $4.5 \mathrm{~m} 2$ & $(4.5 / 2480) \times 100=0.18 \%$ \\
\hline Potholes & $4.97 \mathrm{~m} 2$ & $(4.97 / 2480) \times 100=0.2 \%$ \\
\hline Raveling & $254.49 \mathrm{~m} 2$ & $(254.49 / 2480) \times 100=$ \\
& $0.26 \%$ \\
\hline Rutting & $0.025 \mathrm{~mm}$ & - \\
\hline
\end{tabular}

Calculation of Final Rating Values based on quantity (\%) of distress

Table 6: Calculation of Final Rating Values as per IRC: 82-2015

\begin{tabular}{|c|c|c|c|c|}
\hline $\begin{array}{c}\text { Type of } \\
\text { Distress }\end{array}$ & Input & $\begin{array}{c}\text { Distress } \\
\text { Rating }\end{array}$ & $\begin{array}{c}\text { Weightage } \\
\text { (Multiplier } \\
\text { Factor) }\end{array}$ & $\begin{array}{c}\text { Weighted } \\
\text { Rating } \\
\text { Value }\end{array}$ \\
\hline Cracking & $4 \%$ & 2.1 & 1 & 2.1 \\
\hline Potholes & $0.2 \%$ & 1.7 & 0.5 & 0.85 \\
\hline Raveling & $10.26 \%$ & 1.1 & 0.75 & 0.825 \\
\hline Settlements & $0 \%$ & 3 & 0.75 & 2.25 \\
\hline Rutting & $25 \mathrm{~mm}$ & 1 & 1 & 1 \\
\hline \multicolumn{5}{|c|}{ Final Rating Value } \\
\hline \multicolumn{6}{|c|}{ Condition } & Fair \\
\hline
\end{tabular}

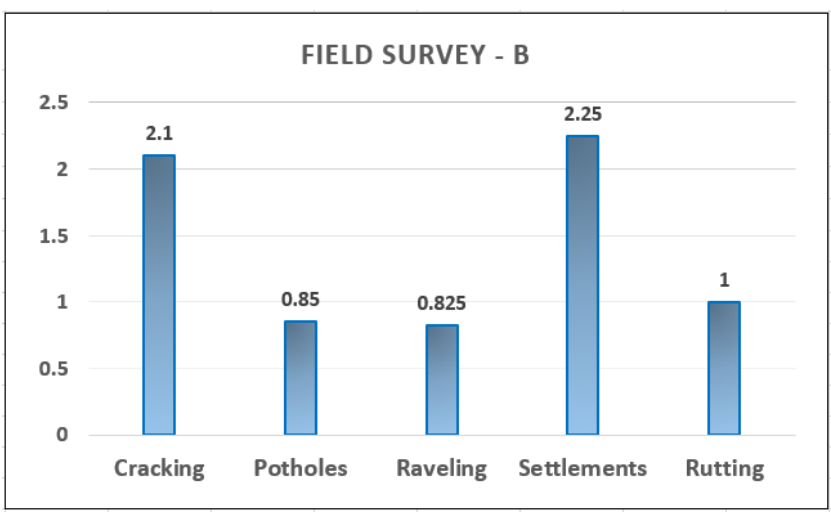

Graph 2: Observed distress rating value for Field Survey - B For field survey $-\mathrm{B}$, the final rating value is obtained 1.405 which is between 1.1 to 2.0 and according to that the road is in fair condition.

3. Surface Distress Measurement for Field Survey - C: Name of the road: - Ravet Gaothan school to Livle Gaothan road, Pimpri Chinchwad, Pune.

Carriageway width: $-7 \mathrm{~m}$

Type of Pavement: - Asphalt Pavement

Chainage test section: - 0 to $1.5 \mathrm{~km}$

Ravet Gaothan School to Livle Gaothan road Pimpri Chinchwad Pune. This road is under PCMC scheme. The construction work of this road started in 2008 and ended in 2008. The total road length to be constructed is $1500 \mathrm{~m}$ with a structural layer of Granular Sub-base course of $150 \mathrm{~mm}$ thick, wet Mix Macadam layer of 150mm thick, Bituminous bound macadam layer of $75 \mathrm{~mm}$ thick, $20 \mathrm{~mm}$ premix bituminous carpet, Liquid seal coat. Many large potholes appeared after every rainy season; hence patchwork was done every year.

Summary of Surface Distress Measurement of Asphalt Pavement:

Table 7: Summary of Surface Distress Measurement of Asphalt Pavement, chainage section 0 to $1.5 \mathrm{~km}$ as per IRC: 82-2015

\begin{tabular}{|c|c|c|}
\hline Type of Distress & Total & \% Distress \\
\hline Cracking & $865 \mathrm{~m} 2$ & $(865 / 10500) \times 100=12 \%$ \\
\hline Edge Breaking & $17.35 \mathrm{~m} 2$ & $(17.35 / 10500) \times 100=0.16 \%$ \\
\hline Bleeding & $43.8 \mathrm{~m} 2$ & $(43.8 / 10500) \times 100=0.42 \%$ \\
\hline Potholes & $13 \mathrm{~m} 2$ & $(13 / 10500) \times 100=0.14 \%$ \\
\hline Raveling & $1008.33 \mathrm{~m} 2$ & $(1008.33 / 10500) \times 100=$ \\
$10.5 \%$
\end{tabular}

Calculation of Final Rating Values based on quantity (\%) of distress:

Table 8: Calculation of Final Rating Values as per IRC: 82-2015

\begin{tabular}{|c|c|c|c|c|}
\hline $\begin{array}{c}\text { Type of } \\
\text { Distress }\end{array}$ & Input & $\begin{array}{c}\text { Distress } \\
\text { Rating }\end{array}$ & $\begin{array}{c}\text { Weightage } \\
\text { (Multiplier } \\
\text { Factor) }\end{array}$ & $\begin{array}{c}\text { Weighted } \\
\text { Rating } \\
\text { Value }\end{array}$ \\
\hline Cracking & $12 \%$ & 1.4 & 1 & 1.4 \\
\hline Potholes & $0.14 \%$ & 1 & 0.5 & 0.5 \\
\hline Raveling & $10.5 \%$ & 1 & 0.75 & 0.75 \\
\hline Settlements & $1.2 \%$ & 1.7 & 0.75 & 1.275 \\
\hline
\end{tabular}

Published By:

Blue Eyes Intelligence Engineering and Sciences Publication (C) Copyright: All rights reserved.

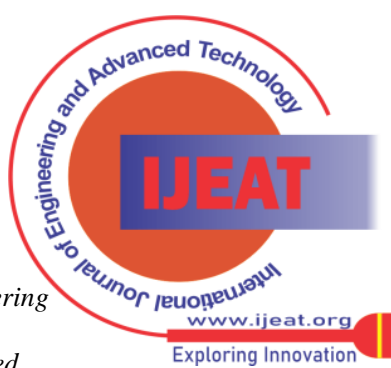


Examine the Underlying Causes of Flexible Pavement Deteriorations, Methods of Maintenance and Pavement Condition Rating

\begin{tabular}{|l|l|c|c|c|}
\hline Rutting & $15 \mathrm{~mm}$ & 1 & 1 & 1 \\
\hline \multicolumn{3}{|c|}{ Final Rating Value } & 0.985 \\
\hline Condition & Poor \\
\hline
\end{tabular}

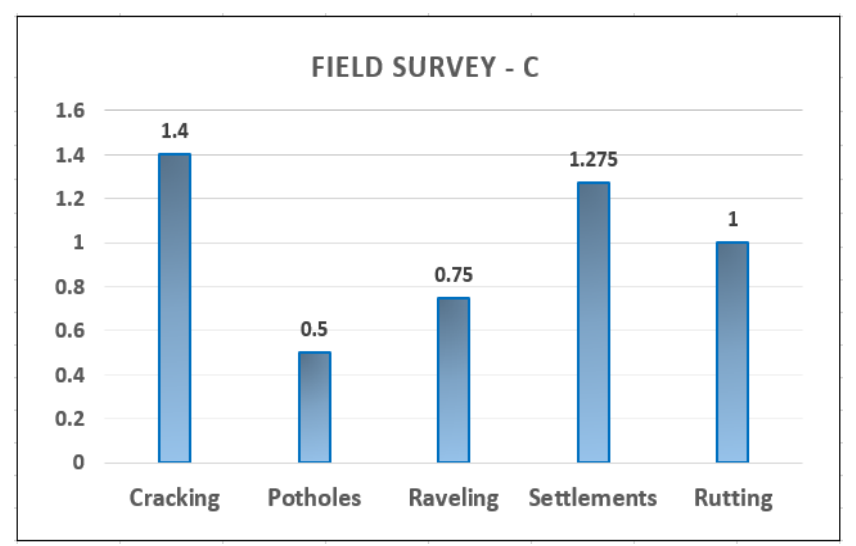

Graph 3: Observed distress rating value for Field Survey - C For field survey $-\mathrm{C}$, the final rating value is obtained 0.985 which is in between 0 to 1.0 and according to that, the road is in poor condition.

\section{Summary of Surface Distress Measurement of Asphalt} Pavement:

Table 9: Summary of Surface Distress Measurement of Asphalt Pavement, chainage section 0 to $1.5 \mathrm{~km}$ as per IRC: 82-2015

\begin{tabular}{|c|c|c|}
\hline Type of Distress & Total & \% Distress \\
\hline Cracking & $178.43 \mathrm{~m} 2$ & $(178.43 / 1680) \times 100=11.5 \%$ \\
\hline Edge Breaking & $3.99 \mathrm{~m} 2$ & $(3.99 / 1680) \times 100=0.24 \%$ \\
\hline Potholes & $2.62 \mathrm{~m} 2$ & $(2.62 / 1680) \times 100=0.16 \%$ \\
\hline Raveling & $170 \mathrm{~m} 2$ & $(170 / 1680) \times 100=10.2 \%$ \\
\hline Settlement & $17.7 \mathrm{~m} 2$ & $(17.7 / 1680) \times 100=1.05 \%$ \\
\hline Rutting & $20 \mathrm{~mm}$ & - \\
\hline
\end{tabular}

Calculation of Final Rating Values based on quantity (\%) of distress:

Table 10: Calculation of Final Rating Values as per IRC: 82-2015

\begin{tabular}{|c|c|c|c|c|}
\hline $\begin{array}{c}\text { Type of } \\
\text { Distress }\end{array}$ & Input & $\begin{array}{c}\text { Distress } \\
\text { Rating }\end{array}$ & $\begin{array}{c}\text { Weightage } \\
\text { (Multiplier } \\
\text { Factor) }\end{array}$ & $\begin{array}{c}\text { Weighted } \\
\text { Rating } \\
\text { Value }\end{array}$ \\
\hline Cracking & $11.5 \%$ & 1.5 & 1 & 1.5 \\
\hline Potholes & $0.16 \%$ & 1.1 & 0.5 & 0.55 \\
\hline Raveling & $10.2 \%$ & 1 & 0.75 & 0.75 \\
\hline Settlements & $1.05 \%$ & 1.1 & 0.75 & 0.82 \\
\hline Rutting & $20 \mathrm{~mm}$ & 1 & 1 & 1 \\
\hline \multicolumn{6}{|c|}{ Final Rating Value } & 0.924 \\
\hline \multicolumn{7}{|c|}{ Condition } \\
\hline
\end{tabular}

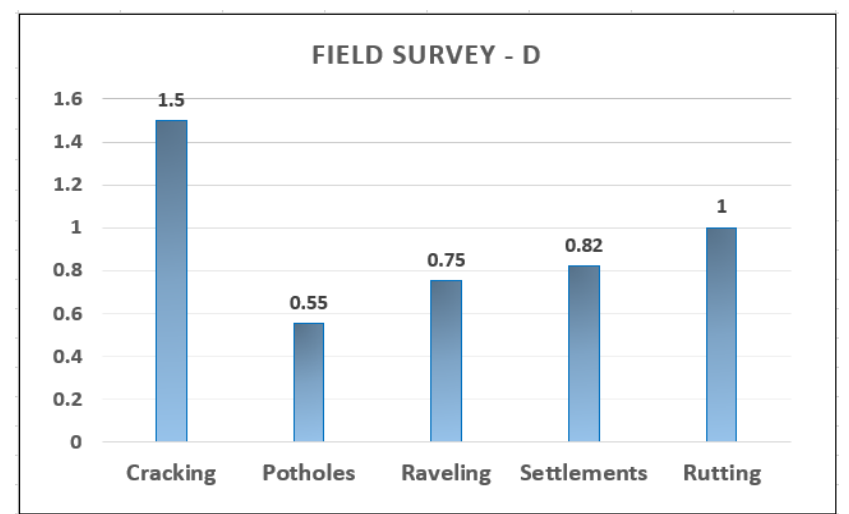

Graph 4: Observed distress rating value for Field Survey - D
For field survey $-\mathrm{D}$, the final rating value is obtained 0.924 which is in between 0 to 1.0 and according to that, the road is in poor condition.

Hence based on the condition of roads, it is necessary to identify proper maintenance and rehabilitation treatments based on the severity levels of the various distresses. And cost-effectiveness is to be carried out to identify the most cost-effective treatment.

\section{RESULT AND DISCUSSION}

\section{A. RESULTS}

After compiling data from the observations, Table 11 shows the rating for field survey - A, field survey - B, field survey $\mathrm{C}$, and for field survey $-\mathrm{D}$. Obtained final values as shown in the following table:

Table 11: Summary of Final Rating Values of field Surveys

\begin{tabular}{|c|c|c|c|c|}
\hline $\begin{array}{c}\text { Type of } \\
\text { Distress }\end{array}$ & $\begin{array}{c}\text { Field } \\
\text { Survey - A }\end{array}$ & $\begin{array}{c}\text { Field } \\
\text { Survey - B }\end{array}$ & $\begin{array}{c}\text { Field } \\
\text { Survey - C }\end{array}$ & $\begin{array}{c}\text { Field } \\
\text { Survey - D }\end{array}$ \\
\hline Cracking & 2.7 & 2.1 & 1.4 & 1.5 \\
\hline Potholes & 0.9 & 0.85 & 0.5 & 0.55 \\
\hline Raveling & 1.5 & 0.825 & 0.75 & 0.75 \\
\hline Settlements & 2.25 & 2.25 & 1.275 & 0.82 \\
\hline Rutting & 1 & 1 & 1 & 1 \\
\hline
\end{tabular}

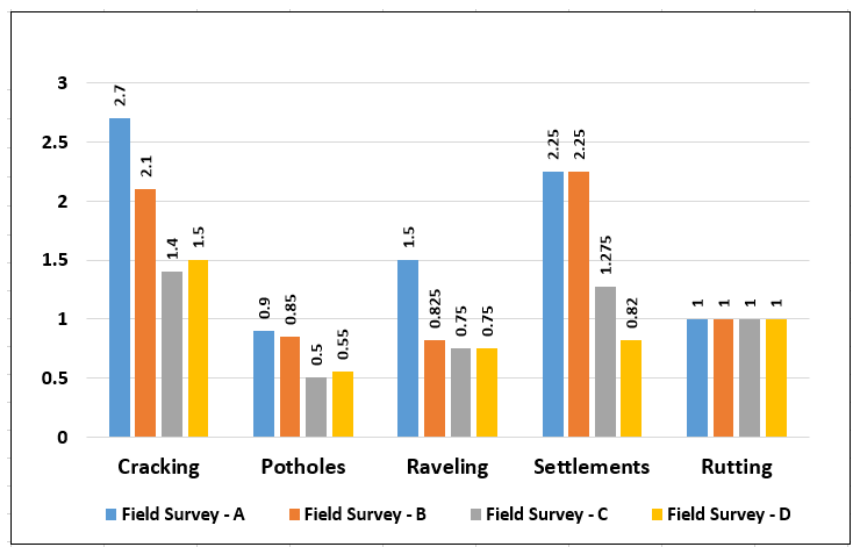

Graph 5: Observed distress rating value for Field Surveys Field Survey - A: In Shinde vasti chowk to Iskon temple road, Ravet Pimpri Chinchwad, Pune was rated as Fair Condition road according to IRC method of rating flexible pavements.

Field Survey - B: Road besides D’Mart, Survey No 29, Ravet Pimpri Chinchwad, Pune was rated as Fair Condition road according to IRC method of rating flexible pavements.

Field Survey - C: Road in front of Dmart, Survey No 29, Ravet Pimpri Chinchwad, Pune was rated as a Poor Condition road according to IRC method of rating flexible pavements.

Field Survey - D: Ravet Gaothan school to Livle Gaothan road, Pimpri Chinchwad, Pune was rated as Poor Condition road according to IRC method of rating flexible pavements. Therefore, different maintenance treatments were recommended according to the severity levels of different distresses and the pavement condition rating.

Published By:

Blue Eyes Intelligence Engineering and Sciences Publication 


\section{B. TREATMENT RECOMMENDED}

Treatment of alligator cracking may be done depending upon their severity [11].

Alligator Cracking: a) Crack sealing by bitumen emulsions. b) Crack sealing by rubberized and modified bitumen. c) Milling and surface recycling.

Longitudinal Cracking: a) Crack sealing preferably using rubberized bitumen. b) Remove and replace the cracked pavement layer with a fresh overlay.

Transverse Cracks: Transverse cracks may be treated using a slurry seal or rubberized bitumen.

Edge Cracking: a) Promote good drainage along the edge of the road. b) Remove the dirty, poor drainage shoulder material and replace it with a more permeable material. c) If the truck traffic is substantial, place a considerably thick structural overlay on the road surface of the order of $75-100$ $\mathrm{mm}$ of hot mix to provide adequate support for heavier vehicle load.

Edge Breaking: The affected area's shoulder and sidewalk materials could be completely removed and replaced with a normal segment with vertical sides. Compaction can be done on both the sidewalks and the shoulders at the same time. The shoulders should have enough slope to allow water to flow away.

Potholes: Potholes should be patched promptly with the readymade cold mix or hot mix asphalt.

Raveling: a) Apply fog seal with diluted emulsified asphalt binder. b) Apply slurry seal. c) Overlay with dense graded asphalt mix

Slippage: Removing the surface coating across the damaged area up to the point that the surfacing and the layer underneath have a strong contact, then patching the area with premix material after adding a tack coat.

Shoving: The rectification consists of removing the material in the affected area down to a firm base and laying a stable premix patch.

Rutting: Any layer exhibiting rutting must be removed (milled) completely and replaced with a more stable mix course.

\section{REMEDIAL MEASURES TO AVOID FAILURE OF PAVEMENTS}

1. Provision of adequate and appropriate designs.

2. Decongestion of the roads.

3. Maintenance of the roads.

4. Provision of highway facilities.

5. Adequate soil tests in road construction.

6. Appropriate road construction materials.

7. Enhanced use of other modes of transportation.

\section{PREVENTIVE MAINTENANCE AND}

\section{REHABILITATION OF ASPHALT PAVEMENTS}

Importance of Maintenance: Maintenance of Bituminous surfacing offers numerous benefits for the preservation of road assets [10].

1. Reduction in the rate of deterioration and improvement in the life of a road.

2. Reduction in Vehicle Operation Costs.

3. Reduction in rate of accidents.

4. Keeping roads traffic worthy in all weathers
5. Reduction in pollution due to reduced fuel consumption on the well-maintained pavement surface.

It is undertaken by the road maintenance staff almost around the year, as and when needed. It involves mainly patching potholes which is one of the most extensive and expensive pavement maintenance activities. The following types of Pathing methods are recommended:

Patching with Hot Mix Asphalt (HMA): In this method, the pothole is cleaned off loose debris and dirt and a tack coat (usually bitumen emulsion) is applied. Dense graded HMA such as BC grading is then placed in the pothole and is compacted immediately with a roller before the mix cools down to 80 degrees Celsius. Patches should not be made with water trapping asphalt mixes such as Premix Carpet (PMC) and SDBC. These will not last long. For small potholes, either a small roller or a vibratory plate can be used. The HMA should preferably be compacted in $75 \mathrm{~mm}$ lifts. The compacted patch should be slightly above ( $3 \mathrm{~mm}$ to $5 \mathrm{~mm}$ ) the adjacent road surface to allow for further densification by traffic. If properly done, patches with HMA have a reasonably good service life. It is preferred in hot and dry weather.

Patching with spray injection method: Spray injection method uses specialized truck-mounted equipment which can do the following functions: blow debris from the pothole; blow-dry moist pothole; spray emulsion tack coat in the pothole; blow aggregate and bitumen binder (usual emulsion) together into the pothole, and then cover the patch with aggregate. Because aggregate and emulsion are propelled into the pothole with high-pressure air, no further compaction is usually required. The success of the spray injection method depends heavily on the skill of the operator.

Patching with readymade cold mix: The Kandhal readymade pothole mix which is an IRC standard, IRC 116-2014 "Specification for Readymade Bituminous Pothole Patching Mix Using Cut Back Bitumen" may be used. This mix has performed well in India. It can be used throughout the year from the hot desert climate of Rajasthan to the hot/wet climate of northeastern India to $-40^{\circ} \mathrm{C}$ temperatures in the Leh-Ladakh area. Its service life is equal to or more than that of the hot mix. Its final in-place cost in the pothole is less than that of the hot mix asphalt.

Preventive Maintenance and Rehabilitation: it is used to improve or extend the functional life of pavement surfaces while still in fair to good condition.

Fog Seals: It consists of applying diluted slow-setting emulsion with a bitumen distributor without an aggregate cover to stabilize the surface of the existing oxidized asphalt surface which is on verge of developing raveling and seal minor surface cracks. The application rate of fog seal depends on the surface texture of the existing pavement so that the applied bitumen residue barely fills the interstices between exposed aggregate particles. Too much application would result in the slippery pavement which can cause accidents, especially on high-speed roads. Therefore, fog seal may have to be applied at lighter rates in 2-3 repetitive applications to

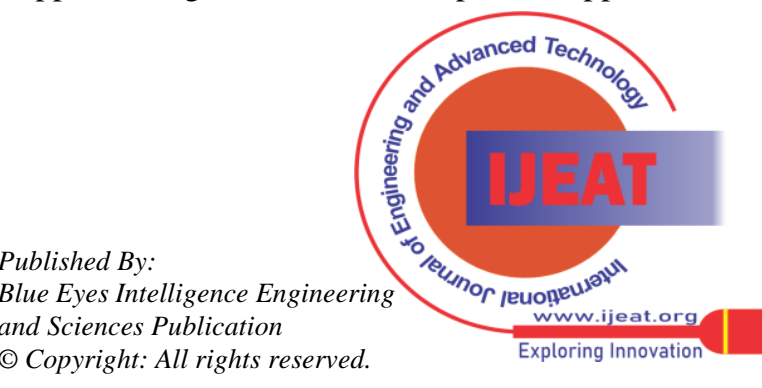


ensure excessive bitumen binder is not used. In case of accidental application of excessive fog seal, sharp sand should be sprinkled and rolled on a hot day.

Surface Dressing: It involves an application by spraying of the proper grade of paving bitumen or rapid setting cationic emulsion to a previously prepared surface followed by application of cover aggregate of appropriate size and gradation and well rolled in place. Single coat surface dressing consists of spraying a layer of bitumen and spreading one layer of cover aggregate and rolling. The two-coat surface dressing consists of a rolled single-coat surface dressing followed by a second coat of binder and another layer of cover aggregates and rolling again. The size of aggregate used in the second layer is smaller than that of the first layer aggregate so that it may interlock in the surface interstices of the first layer. Slurry seals: It consists of a proportioned, blended, and uniformly distributed mixture of mineral aggregate (mostly fine aggregate), water, slow settling cationic bitumen emulsion, and additives (if needed) over a prepared surface. There are three types of slurry seals based on the thickness of application and corresponding gradations of aggregate and residual binder contents. The thickness of the application is $2 \mathrm{~mm}$ to $3 \mathrm{~mm}$ for type I; $4 \mathrm{~mm}$ to $6 \mathrm{~mm}$ for type II; and $6 \mathrm{~mm}$ to $8 \mathrm{~mm}$ for type III. Type I slurry has the finest aggregate gradation, highest asphalt residue content, and lowest application rate, while type III has the coarsest gradation, lowest asphalt residue content, and highest application rate. Therefore, type III produces the maximum improved friction and improved wearing surface as compared with other types. Micro-surfacing: It is similar to a slurry seal, the primary difference being the former uses a modified (polymer or rubber latex) bitumen emulsion. Again, two types of micro-surfacing are specified in the IRC code with corresponding aggregate gradations and residual binder contents. The thickness of the application is $2 \mathrm{~mm}$ to $3 \mathrm{~mm}$ for type II and $6 \mathrm{~mm}$ to $8 \mathrm{~mm}$ for type III. There is no type I. Type III has a coarser gradation than type II. Type III is usually used for rut filling and texturing on high-volume roads.

Crack Sealing: Cracks need to be sealed to prevent intrusion of incompressible materials such as soil into the crack, and to prevent ingress of water into the underlying pavement layers which will be detrimental to the performance of the pavement. Thin cold or hot mix Bituminous overlays: It includes adding plant mixed asphalt cement and aggregate mixtures to the pavement in thicknesses ranging from 15 to $25 \mathrm{~mm}$ dense graded, premix, open-graded, and stone matrix blends.

\section{E. COST-EFFECTIVENESS RANKINGS OF VARIOUS MAINTENANCE TREATMENTS}

Cost-effectiveness rankings of various treatments based on the cost ratios are calculated as the ratio of the cost of each treatment and the cost of an overlay.

This is expressed as Cost ratio $=$ Cost of treatment $/$ Cost of overlay

Table 12: Types of various Maintenance treatments

\begin{tabular}{|c|c|c|c|}
\hline Types & $\begin{array}{c}\text { Cost per } \mathbf{~ m}^{2} \text { in } \\
\text { rupees }\end{array}$ & $\begin{array}{c}\text { Cost } \\
\text { Ratio }\end{array}$ & Rank \\
\hline Crack Sealing & 43 & 0.057 & 1 \\
\hline Micro surfacing & 64 & 0.084 & 2 \\
\hline Surface Dressing & 79 & 0.105 & 3 \\
\hline
\end{tabular}

Retrieval Number: 100.1/ijeat.D25180410421

DOI:10.35940/ijeat.D2518.0410421

Journal Website: www.ijeat.org

\begin{tabular}{|c|c|c|c|}
\hline Fog Seal & 83 & 0.11 & 4 \\
\hline Slurry Seal & 92 & 0.12 & 5 \\
\hline $\begin{array}{l}\text { Thin cold or hot mix } \\
\text { Bituminous overlays }\end{array}$ & 753 & 1 & 6 \\
\hline
\end{tabular}

Comparing various maintenance treatments for wearing course distresses concerning thin overlays of cold or hot mix bituminous, crack sealing is the most cost-effective but is suitable for low to medium severity distresses. Micro-surfacing can't be used for highly weathered condition pavement, this is also suitable for low to medium severity pavement. Fog seal and slurry seal are suitable for low to medium severity distresses. Surface Dressing is suitable for all severity pavements from low to high severity. Surface dressing and Micro-surfacing are long-lasting treatments as compared to Fog seal, crack seal, and slurry seal. Therefore, fog seal, crack seal, micro-surfacing, slurry seal, can be used for fair to good condition roads. Surface dressing and Thin cold or hot mix bituminous overlays can be used for poor condition roads.

\section{CONCLUSIONS}

Various types of distress were observed on the four urban roads during the physical survey carried out. The causes of this distress were the frequent excavations carried out for several maintenance activities like drainage leakage, water supply leakage, Electric cables, etc., these activities lead to the formation of potholes after the rainy season if not filled properly. Heavy vehicle traffic load, faulty stormwater connectivity, bitumen surface-level issue, lack of preventive maintenance was also some of the causes of distresses of these roads.As per the final rating values, Shinde vasti chowk to Iskon temple road, Ravet Pimpri Chinchwad Pune (field survey - A) and Road besides D'Mart, Survey No 29, Ravet Pimpri Chinchwad Pune (field survey - B) roads were found to be in fair condition, while the Road in front of Dmart, Survey No 29, Ravet Pimpri Chinchwad, Pune (field survey C) and Ravet Gaothan school to Livle Gaothan road, Pimpri Chinchwad, Pune (field survey - D) were in poor condition.

Therefore, different maintenance treatments were recommended according to the severity levels of different distresses and the pavement condition rating. Treatments like fog seal, crack seal, micro-surfacing, and slurry seal, can be used for fair condition road since timely maintenance activities will prevent the further deterioration of the road. Surface Dressing and Thin overlays of cold or hot mix bituminous can be used for Poor condition roads.

\section{REFERENCES}

1. Ahmed A. Eltahan, Jerome F. Daleiden, and Amy L. Simpson Effectiveness of Maintenance Treatments of Flexible Pavements. In Transportation Research Record: Journal of the Transportation Research Board, No.1680, Transportation Research Board of the National Academies, Washington, D.C, 2005, 99-0949.

2. Ankur Singh, A.N. Arora and Pawan Kalla. Evaluation of a generic readymade cold pothole patching mix including field performance and cost-effectiveness. Indian Highways, September 2012, 29-38.

\section{Published By:}

Blue Eyes Intelligence Engineering and Sciences Publication

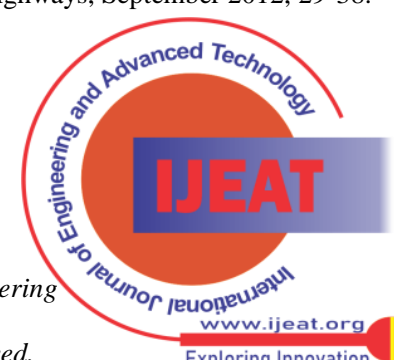
Exploring Innovation 
3. Dennis A. Morian, Yanqing Zhao, Janice Arellano, and Donald E. Hall. Asphalt Pavement Rehabilitation Treatment Analysis of 20 Years of Performance: Journal of the Transportation Research Board, No.1905, Transportation Research Board of the National Academies, Washington, D.C, 2005, 36-43.

4. IRC: 82-2015, Code of Practice for Maintenance of Bituminous Road Surfaces.

5. L. Udayakumar, R. Vivian Robert, M.S. Amarnath. Ranking technique for prioritization of arterial and sub arterial roads for maintenance management. Indian Highways, 2008, 41-51.

6. Magdi M. E. Zumrawi. Investigating Causes of Pavement Deterioration. International Journal of Civil Engineering and Technology, Volume 7, Issue 2, March-April 2016, 203-214.

7. MORTH: 2013, Specifications for road and bridge works.

8. Nirmal Dhakal, Mostafa A. Elseifi, Zhongjie Zhang. Mitigation strategies for reflection cracking in rehabilitated pavements - A synthesis. International Journal of Pavement Research and Technology, Volume 9, 2016, 228-239.

9. Prithvi Singh Kandhal. Bituminous Road Construction in India. PHI Learning Private Limited, Delhi, 2017, Second Revised Edition.

10. Rafiqul A. Tarefder, Mohiuddin Ahmad, Mohammad I. Hossain. Pavement maintenance procedures with and without milling materials. International Journal of Pavement Research and Technology, Volume 9, January 2016, 20-29.

11. Samuel Labi, Geoffrey Lamptey, Sravanthi Konduri, and Kumares C. Sinha. Analysis of Long-Term Effectiveness of Thin Hot-Mix Asphaltic Concrete Overlay Treatments: Journal of the Transportation Research Board, No.1940, Transportation Research Board of the National Academies, Washington, D.C., 2005, 3-12.

12. Teiborlang Lyngdoh Ryntathiang. Pavement Condition Index for accessing the rural road pavements: A case study of the Assam rural roads. Indian Highways, October 2011, 41-57.

13. Yang H. Huang. Pavement Analysis and Design. Pearson Prentice Hall, 2014, Second Edition.

\section{AUTHORS PROFILE}

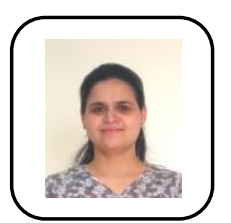

Ms. Pooja Kherudkar, M. Tech Student from Department of Civil Engineering, Government College of Engineering, Pune, Maharashtra, India.

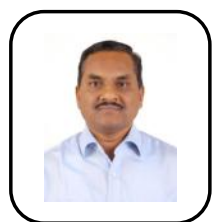

Dr. Namdeo A. Hedaoo, working as Associate Professor in the Department of Civil Engineering, Government College of Engineering, Pune, Maharashtra, India. Specialization in structural and completed Ph.D. in Civil Engineering. He is the Committee member of second revision of IS 3370 (Part 1,2,3): 2021 titled "Concrete Structures for Retaining Aqueous Liquids Code of Practice by the Bureau of Indian Standards New Delhi.

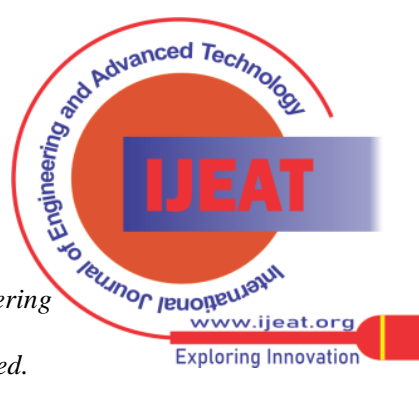

